\title{
Psycholinguistic Aspects of Reproducing the Chinese Military and Political Discourse in Ukrainian
}

\section{Психолінгвістичні аспекти відтворення китайськомовного військово-політичного дискурсу українською мовою}

Tetiana Korolova

Dr. in Philology, Professor, Head of the Department of Faculty of Translation, Theoretical and Applied Linguistics

\section{Тетяна Корольова}

доктор філологічних наук, професор, завідувач кафедри перекладу і теоретичної та

прикладної лінгвістики

E-mail: kortami863@gmail.com orcid.org/0000-0003-3441-196X

\section{Oleksandra Popova}

Dr. in Pedagogy, Associate Professor,

Dean of the Foreign Languages

Department

\section{Олександра Попова}

доктор педагогічних наук, доцент, декан факультету іноземних мов

E-mail: alex-popova@ukr.net orcid.org/0000-0002-6244-5473

South-Ukrainian K.D. Ushinskyi

National Pedagogical University

$\triangle 26$, Staroportofrankivska Str., Odesa, Ukraine, 65020
Державний заклад «Південноукраӥнський національний педагогічний університет імені К.Д. Уиинського» $\triangle$ вул. Старопортофранківська, 26, м. Одеса, Україна, 65020

Original manuscript received September 23, 2018

Revised manuscript accepted March 29, 2019 


\section{ABSTRACT}

The article is aimed at studying psycholinguistic issues regarding the interpretation variability and linguocultural accommodation of conceptual basis representing the determinants of the Chinese military and political discourse by the Ukrainians. The topicality is stipulated by great interest of the scientists in the fields of psycholinguistics, linguistic culturology, translation studies as to the semantic content within the view of the world displayed by ethnic groups from The Orient. The determinants of the Chinese military and political discourse (discourse, concept, concept sphere, linguistic component, extra-linguistic component) are specified in the article. The Chinese-language military-political discourse is understood as a totality of verbalized oral and written texts created in the context of the politics-oriented communication; ideographic and symbolic embodiment of the national concept sphere, which is governed by the national and culture-centric tactical and strategic vectors of the conflict-free interaction performed by communicants in the spheres of politics, economy, military-industry, international relations. The linguistic phenomena enable the Chinese military and political discourse to be actualized as well as the means of their reproduction in the Ukrainian language [replication (equivalent translation), transliteration, transcoding, descriptive translation, commentary; the communicationequal translation strategy; the redirection strategy where cultural and linguistic adaptations are applied]. The prospects of our further research are seen in the study of tactical and strategic vectors which may determine the peculiarities of reproducing the syntactic component of the discourse under study into the Ukrainian language.

Key words: Chinese military and political discourse, concept, concept sphere, view of the world, language, culture, reproduction means.

\section{Вступ}

Актуальність започаткованого дослідження зумовлена неабияким інтересом науковців у галузі психолінгвістики, лінгвокультурології, перекладознавства до змістового контенту картини світу етносу країн Сходу, зокрема імпліцитного «навантаження» експліцитного фрейму культурно-релятивних концептів, що реалізуються як вербальними засобами, так i невербальними, 3 одного боку; 3 іншого, до необхідності адекватного декодування ментальних i соціальних стереотипів представників цієї давної культури та коректного лінгвістичного оформлення «традиційно-маркованого скарбу» засобами іншої мови, тобто перекладу, доступного реципієнту.

Численні праці, присвячені вивченню мови в нерозривному зв’язку з культурою певного етносу, підтверджують універсальність, 
але й в той час й унікальність, мови як багатофункційного цілісного механізму, що забезпечує передавання різнопланової інформації через відповідний інструментарій від покоління до покоління в межах одного етносу, між різними культурними спільнотами в діахронії та синхронії.

Якщо розглядати мову в площині психології, мова віддзеркалює складні багатоаспектні процеси когнітивної діяльності, рефлексує стан, емоційні переживання, настрій тощо. Мову корелюють із мисленням, свідомістю, інтелектом, розумом. О. Леонтьєв розуміє мову як єдність спілкування й узагальнення, як систему значень, що актуалізуються в предметній та вербальній формах існування (Леонтьев, 1969). Саме «мовна свідомість» (тобто свідомість, опосередкована значеннями) є допоміжним інструментом до розуміння «образу світу» («картину світу»). Кореляції картин світу з відображенням у психіці людини предметної навколишньої дійсності, що опосередкована відповідними когнітивними схемами, 3 результатом минулого того народу, частиною якого ми себе вважаємо, є ключовими моментами мовленнєвої поведінки людини (Леонтьев, 1969). Таке відображення навколишнього середовища, на думку науковця, піддається свідомої рефлексії, що віддзеркалюється в продукуванні мовлення (Красных, 2001: 70-71).

Учені наголошують про нерозривний зв'язок феномена «картина світу» 3 мовою, що підтверджують наведені далі цитати: «мова відображає бачення світу, є призмою, через яку мовці бачать навколишнє середовище; мовна призма сприйняття вбудована у свідомість та підсвідомість іiі носіїв» (Уорф, 1960: 135-168); «мова є головним, найяскравішим і найстійкішим показником етносу» (Толстой, 1989: 9); мовний матеріал можна асоціювати 3 найвагомішою інформацією про світ і людину в ньому, його (матеріалу) глибокий аналіз дозволяє проникнути в таємницю людини і мови (Маслова, 2001: 27-28); «картина світу» актуалізується в «мовній картині світу», тобто «дзеркалі мови; в сукупності знань про світ, що відображені в лексиці, фразеології, граматиці» (Красных, 2001: 70-71). Д. Будняк згадує про індивідуальну компоненту людини в комунікації: «мова як універсальний засіб передавання інформації про природу та про всі сфери життя людини й людського суспільства, а також про себе саму, відображає культуру спільноти людей (Budniak, 2003: 19). 
Враховуючи вищенаведене, варто зазначити такі факти: як-от: 1) різні мови по-різному впливають на мислення; 2) реальний світ, більшою мірою, будується несвідомо, на основі мовних норм певної соціально-культурної групи.

Погоджуючись із авторськими баченням сутності психолінгвістичного феномена «мова», можна резюмувати, що мова $\epsilon$ потужним «резервуаром» для предметів і явищ об'єктивного світу, образно-абстрактних феноменів, почуттєво-емоційних переживань люду. Водночас мова виконує функцію вербально-виразну, де вона виступає інструментом для трансформації контенту цього «вмістилища» відповідно до концептуального «етно-бекграунда». Проте слід зазначити, що дослідження інтеркультурної і кроскультурної кореляції мовних картин світу, зокрема в контрастивному аналізі мовних картин країн Заходу і Сходу, залишилися поза колом сучасних наукових розвідок.

Контекст динамічного розвитку співпраці між Україною та Китаєм у багатьох сферах життєдіяльності на тлі подій, що відбуваються на сучасній військово-політичній арені нашої країни, нетривіальної значущості набуває проблема коректного розуміння, тлумачення й усвідомлення згаданої концептосфери Піднебесної. Сьогодні актуалізується потреба у пошуку нових адекватних способів й інструментального апарату для репродукції саме смислу китайськомовного військово-політичного дискурсу українською мовою. 3 огляду на вищезазначене, формулюємо мету запропонованої розвідки: дослідити психолінгвістичні засоби відтворення концептуальної бази детермінантів китайськомовного військово-політичного дискурсу українською мовою. Реалізації окресленої мети сприятиме розв'язання конкретних завдань: 1) специфікувати особливості функціонування детермінантів китайськомовного військово-політичного дискурсу; 2) проаналізувати когнітивне підгрунтя варіативності інтерпретації детермінантів китайськомовного військово-політичного дискурсу при відтворенні їх українською мовою; 3) виявити найбільш ефективні тактико-стратегічні засоби репрезентації іншомовного матеріалу мовою перекладу.

За нашою гіпотезою, вдала ідентифікація досліджуваних детермінантів та їх адекватне тлумачення уможливлює коректну трансформацію китайських культурем мовою перекладу. 
Об'єктом нашого дослідження виступають перекладацькі рішення, в яких маніфестуються певні сигналізатори когнітивного, асоціативного i фоново-культурологічного мислення; предметом аналізу є психолінгвальні і лінгвальні засоби та способи перекладу концептуальних детермінантів студійованого дискурсу, що віддзеркалюють лінгвокультурологічні рішення в друготворі.

Термінологічним фундаментом започаткованого дослідження $\epsilon$ такі психолінгвістичні феномени, як-от: «дискурс», «концепт», «мовна картина світу». Розглянемо їх детальніше.

Враховуючи багатоаспектність функціонального апарату дискурсу, наявність широкого спектру сфер його актуалізації i неоднозначне дефініційного фонду цього феномена, вивченню сутності і структури дискурсу було присвячено чимало праць вітчизняних (Бацевич, 2004, 2010; Бехта, 2004; Ищенко, 2007) та зарубіжних (Греймас \& Курте, 1983; Конт-Спонвиль, 2012; Райзберг, 2009; Серио, 1999; Фуко, 1996; Habermas, 1981) учених.

За енциклопедично-довідниковими джерелами, «дискурс» має такі визначення: - «зв'язний текст у сукупності 3 екстралінгвістичними - прагматичними, соціокультурними, психологічними та іншими чинниками; текст, що функціонує в подієвому аспекті, мовлення, що розглядається як цілеспрямована соціальна дія, як компонент, що бере участь у взаємодії людей та механізмах їх свідомості (когнітивних процесах)»; тобто «втілене в життя» мовлення (Арутюнова, 1990: 136-137); слід вказати, що багато вчених є прихильниками такого погляду (Райзберг, 2009: 125; Конт-Спонвиль, 2012: 156). Низка дослідників розширюють поняття дискурсу за рахунок екстра- або пара-лінгвістичних компонентів комунікації (Серио, 1999: 14-53; Фуко, 1996; Бехта, 2004; Греймас \& Курте, 1983), семантики модально-оцінних конотацій (Habermas, 1981), формування різноманітних мовленнєвих жанрів (Бацевич, 2004: 138), соціальної орієнтації типу мовлення (Карасик, 2000).

3 огляду на теоретичний аналіз поняття «дискурс», розуміємо його як тип комунікативної діяльності, що репрезентується в усній і писемній формах відповідно до тактико-стратегічної спрямованості комунікації i реалізується через лінгвістичні й екстралінгвістичні засоби спілкування з урахуванням особливостей сфери його актуалізації i когнітивно-практичного фундаменту безконфліктної інтеракції. 
Psycholinguistic Aspects of Reproducing the Chinese Military...

Повне розкриття змістової компоненти китайськомовного військово-політичного дискурсу уможливлюється завдяки врахування аутентичної концептосфери його реалізації. У цьому зв'язку доцільним $є$ дослідити семантику феномена «конщепт». Наразі існує п'ять основних напрямів щодо його визначення: когнітивістський, психолінгвістичний, лінгвістичний, лінгвофілософський, лінгвокультурологічний.

У сучасній науці репрезентована низка напрямів дослідження концепту, об'єднаних у дві групи на підставі стилю мислення, «що визначає відношення ментального компонента мовного знака, який об'єктивує концепт, до фрагмента дійсності (референта), до якого відсилає форма цього знака» (Мартинюк, 2011: 40), подібної думки дотримуються представники когнітивістської теорії, деякі з котрих іменують концепт тештальтом (Кубрякова, 2007: 14; Болдырев, 2001: 29). Цікавим є логіко-філософський підхід до трактовки концептів, які можна розглядати як потенційно вербалізовані смисли, тобто передмовно-мовленнєві проекції результатів психічних процесів (Павиленис, 1983).

Психолінгвісти розглядають «конщепт» як «спонтанно функціонуюче в пізнавальній та комунікативній діяльності індивіда базове перцептивно-когнітивно-афективне утворення динамічного характеру, що підкорюється закономірностям психічного життя людини i внаслідок цього за рядом параметрів відрізняється від понять і значень як продуктів наукового опису 3 позицій лінгвістичної теорії» (Залевская, 2001); як глобальну ментальну одиницю, що становить собою квант структурованого знання (Попова \& Стернин, 1999). У визначеннях науковців превалюють кореляції між індивідуальним психічним досвідом й особливостями реалізації психічних процесів людини, що актуалізуються в певні знання.

3 огляду на вищенаведений дефініційний аналіз наукового конструкту, феномену «концепт» надаємо таке визначення: динамічно-гнучка одиниця психічного потенціалу людини, що виникає в процесі дискурсивної інтеракції індивідів, має усвідомлену мовленнєво-вербальну національно-марковану маніфестацію 3 урахуванням особистого когнітивно-перцептивного досвіду в межах певного культурного простору. 
Відзначимо, що лінгвофілософський і лінгвокультурологічний підходи вважаємо визначальними для декодування сутності китайськомовного військово-політичного дискурсу. Наголошуємо на значущості вербальної компоненти актуалізації концепту(тів), тобто мовної картини світу, що відбиває: 1) знання про мову як знакову систему; і 2) знання про світ, об'єктивовані формами мовних знаків. Внутрішній лексикон, сформований на базі вищезазначених знань i організований у єдине ціле - «складне, багатомірне, ієрархічно стратифіковане утворення в мисленні людини, що є невід'ємною частиною її пам'яті й слугує збереженню інформації і забезпеченню легкого доступу до неї за необхідності їі використання в мисленнєвій i мовленнєвій діяльності» (Кубрякова, 1991; Жаботинская, 2009: 382). У цьому зв'язку, зауважимо, що кореляції знань і мови $\epsilon$ основним регулятором розуміння, актуалізації і зберігання ресурсної змістовно-центричної бази про світ.

Оскільки китайська мова належить до категорії ідеографічного письма, коректна ідентифікація плану змісту ієрогліфів уможливлюється завдяки концептуальної обізнаності і фоновими знаннями філософсько-культурологічної спрямованості. Повному відтворенню автентичної семантики досліджуваного дискурсу сприяє адекватне використання перекладацького інструментарію.

\section{Методи та методики дослідження}

Враховуючи тісний зв'язок психолінгвістики і транслатології, що фокусується на спостереженні та аналізі мовного матеріалу в перекладі (Hatzidaki, 2007), констатуємо доцільність використання як психолінгвістичних, так і загальнонаукових та загальнолінгвістичних методів дослідження порушеної проблеми.

Беручи до уваги той факт, що переклад $є$ мисленнєвим процесом, 3 одного боку, i творчим, 3 іншого, задля аналізу результату відтворення детермінантів досліджуваних концептів у неблизькоспоріднених мовах / культурах, раціональним у цьому сенсі видається використання методу аналітичної інтроспекції, що дає можливість відтворити цілісний зміст концептосфери китайськомовного військово-політичного дискурсу на основі існуючих асоціативних зв'язків (зокрема позитивних і негативних 
емоцій i переживань як категоріальних елементів свідомості в сукупності 3 ідеографічно-ієрогліфічним «втіленням» змісту повідомлення). Методика прямого тлумачення слова надала змогу з'ясувати реальну складну картину співвідношення лексичного значення і внутрішньої форми компонентів досліджуваного дискурсу.

Для вирішення поставлених завдань було також використано загальнонаукові та загальнолінгвістичні методи дослідження як допоміжні: 1) методи індукції / дедукції, за допомогою яких було проаналізовано та узагальнено теоретичні основи 3 досліджуваної теми, а також систематизовано результати дослідження; 2) метод дефініційного аналізу, за допомогою якого було детерміновано зміст наукових визначень (дефініцій) досліджуваних понять; 3) метод психолінгвістичної оцінки коректності мови перекладу, заснованого на порівнянні спостережень, що отримані під час сприйняття китайського оригіналу та його українського варіанту.

Відзначимо, що доречність практичного використання отриманих знань $з$ порушеної теми було експериментально доведено на базі Державного закладу «Південноукраїнський національний педагогічний університет імені К.Д. Ушинського» на початку 20182019 навчального року. В експерименті взяли участь: 20 студентівмагістрантів, які навчаються за спеціальністю «Переклад», i професійні перекладачі-китаєзнавці (5 осіб). Мета експерименту оцінити якість перекладу студентів; матеріал - китайськомовні публічні виступи політиків та коментаторів, інтерв'ю політиків, протоколи засідань уряду, з’іздів партії, публікації у 3MI, історичні документальні хроніки, політико-нормативні документи й студентські варіанти їх перекладу українською мовою. Критеріями оцінювання виступили такі: - адекватний (добрий переклад); • задовільний переклад; • неадекватний (поганий переклад).

\section{Результати та дискусії}

Відомо, що переклад $\epsilon$ складним процесом відтворення концептуальної картини світу іншою мовою, який передбачає збереження єдності змісту i форми. Перекладач стикається 3 безліччю номінацій, уявлень, значень у процесі реалізацій перекладацький дій-операцій, у центрі яких знаходиться, перш 
за все, слово, що виконую функцію відображення предметнопонятійного змісту. Виокремлення відповідного варіанту потребує певних мисленнєвих зусиль. Це пояснюється «психологічною структурою значення, тобто наявністю системи диференційних ознак значення (семантичних компонентів), що актуалізуються в динаміці комунікації у всій повноті лінгвістичної, психологічної, соціальної обумовленості вживання слова» (Леонтьев, 1971).

Наголошуємо на значущості «асоціативної обробки» значення слова в концептуальному фреймі певної ситуації: декодування $\rightarrow$ трансформування. На думку С. Дейне i Дж. Штормс, саме асоціативні реакції характеризуються рядом факторів, які охоплюють різні, але пов'язані з ними аспекти словосполучень (De Deyne \& Storms, 2008). У даному випадку роль «психолінгвістичних моделей мовної обробки» $є$ вагомою, оскільки вони допомагають у розумінні діалогу (Reitter, 2016). Доцільним здається також застосування герменевтичного підходу до розв'язання завдань нашого дослідження. Погоджуємося із концепцією Салмері Стефано, що саме герменевтична парадигма є стратегією критичної емансипації для розуміння імпліцитного змісту повідомлення (Салмери, 2016).

Сприйняття дійсності в контексті дослідження підпорядкується лінгвістичним нормам китайської мови, які визначаються китайським суспільством, тому перекладач має зробити правильний вибір інструментарію задля перекодування змісту оригінального тексту мовою перекладу. Перцепція китайськомовних текстів базується на семантико-філософсько-концептуальному значенні слів-ієрогліфів. Отже, коректне сприйняття цілісного «повідомлення» передбачає розуміння перекладачем його концептуального фону. Перекладач має мислити системно, оскільки «системне мислення дозволяє перекладачу вийти за межі того, що видається ізольованими та незалежними подіями, та побачити структури, що перебувають у їхній основі» (Ребрій \& Ребрій, 2018).

3 огляду на вищезазначене, доцільним здається репрезентувати сутність китайськомовного військово-політичного дискурсу та його експлікацію задля виявлення адекватних засобів відтворення детермінантів зазначеного дискурсу українською мовою.

Основою дослідження китайськомовного військовополітичного дискурсу стали праці М. Іщенка (Ищенко, 2007) та 
О. Шейгал (Шейгал, 2004). Серед китайських науковців цієї галузі варто відмітити Ван Сюй (Ван, 2016).

Розглянемо двокомпонентний склад поняття «військовополітичний дискурс».

Під «військовим дискурсом» розуміємо дискурс про війну в традиційній і в сучасній їі формах, тобто «дискурс військових про війну (жанр «доповіді» або «зведення»), політиків про війну (різновид політичного дискурсу в жанрі «інтерв’ю»), дискурс засобів масової інформації, які висвітлюють військові дії тощо» (Ищенко, 2007). Полемічність військового дискурсу схиляє науковця до констатування близькості й схожості між військовим та політичним дискурсами, зокрема «тоталітаристським». Автор аналогізує цілеспрямованість двох дискурсів, а саме націляння i політичного, й військового дискурсів на «знищення «бойової потужності» супротивника - озброєння (тобто думок і аргументів) i особового складу (дискредитація особистості опонента)» (Ищенко, 2007).

Семіотичне походження компонентів військово-політичного дискурсу надає змогу виокремити їх «загальні» маркери та покласти в основу їх лінгвістичної інтерпретації. Так, на думку О. Шейгал, мова політики, політична комунікація, політичний дискурс - терміни, які $є$ взаємопов'язаними. Вона ототожнює терміни «політичний дискурс» та «політична комунікація», а мову політики розглядає як «структуровану сукупність знаків, які утворюють семіотичний простір політичного дискурсу» (Шейгал, 2004). Авторка асоціює політичний дискурс із боротьбою за владу, заволодінням нею та іiі збереженням, що реалізується через комунікативну функцію мови. Формою маніфестації згаданої функції науковець вважає звернення, лозунгі, заклики, законодавчі акти, які мобілізують до дій. Результатом рецепції їх змісту адресатом $є$ формування відповідного емоційного поля, на тлі якого розвиваються такі почуття, як-от: надія, гордість за країну, впевненість, ворожість, ненависть, довіра, підтримка тощо. (Шейгал, 2004). Отже, загальними складовими концептосфер військового й політичного дискурсів виступають коНцеПти ВІЙНА, ПОЛІТИКА, СУПРОТИВНИК (ОПОНЕНТ), КОМУНІКАЦІЯ.

Схожість концептосфер військового й політичного дискурсів дозволяє їх об’єднати в асоціативному й лінгвістичному планах. 
Відносно культурологічної детермінанти китайськомовного політичного дискурсу зауважимо, що особливості реалізації зазначеного феномена базуються на морально-ціннісних постулатах духовної скарбниці народу Піднебесної, визначених традиціями іiі кожного етносу. Неможна обійти увагою й той факт, що контент політичної складової Китаю формувався через вплив філософських і релігійних вірувань, як-от: конфуціанство, даосизм, легізм, буддизм тощо (Ван, 2016).

Відомо, що Китай протягом тривалого часу еволюціонував як автономна «ізольована» держава, а його населення сприймало давню цивілізацію центром світу, яка має багатоманітні досягнення (中国 - перекл. 3 кит. мови Середнє ичарство, Центральна держава). Таке народне ставлення до рідної країни зумовлено історичними чинниками, зокрема впливу ідеології імперського періоду, коли одна династія змінювала іншу, воювала 3 внутрішніми та зовнішніми ворогами, але подібне розуміння не трансформувалося. Централізована імператорська влада мала за мету утримувати порядок і стабільність у державі, що знайшло своє відображення та пояснення в конфуціанстві. Отже, з боку держави ми спостерігаємо репрезентацію концептів ПОРЯДОК, СТАБІЛЬНІСТЬ, ВЛАДА.

Наразі сформовану гармонію у відносинах між владою i суспільством китайці намагаються не порушувати; вони демонструють відданість i вірність державі, історичним традиціям та високий рівень громадянського свідомості, тобто риси національного характеру. Інша сторона національного характеру китайців пов'язана із соціальним втіленням традиційнонаціональних людських цінностей, що виражено в таких рисах, як-от: працелюбність, терпіння, смиренність, дисциплінованість, ввічливість, чесність, невибагливість і ощадливість. Коріння соціально-політичної поведінки китайців «сховані» в конфуціанській патерналістській концепції, згідно 3 якою держава уподібнюється великій родині (колективізм), імператор виконує функції батька («лідер», «кращий»), підлеглі («прості люди», «нижчі класи») підкорюються та поважають правителів («людей благородного стану»), як молодь («молодші») літніх людей («старших»). Відзначимо, що саме національні риси характеру, сформовані на фундаменті конфуціанства i традицій, забезпечують моральноціннісний авторитет влади, суспільно-державну цілісність 
Піднебесної та економічний прогрес своєї країни. Варто також зазначити про соціальний характер політики реформ і відкритості Уряду Китаю, що проводиться протягом 40 років 3 дотриманням самовдосконалення і розвитку соціалістичної системи, де рушійною силою є партія та уряд. 3 огляду на вищезазначене, як національнотрадиційний компонент концептосфери в межах досліджуваного дискурсу виокремлюємо такі концепти: КОЛЕКТИВІЗМ, ВІДДАНІСТЬ, ТЕРПІННЯ, ДИСЦИПЛІНОВАНІСТЬ.

Специфіка концептосфер китайськомовного військовополітичного дискурсу дає підстави визначити його як сукупність вербалізованих усних i письмових текстів, створених у контексті політико-зорієнтованого спілкування; ідеографічносимволічне втілення національно-маркованої концептосфери, що регламентується народо- й культуроцентричними тактикостратегічними векторами безконфліктної взаємодії інтерлокуторів у сфері політико-економічних, військово-промислових, міжнародних відносин; лінгвістична складова дискурсу маніфестується в специфічному фонетичному, лексичному, граматичному та композиційно-стилістичному оформленні його контенту.

Типовими рисами китайськомовного військово-політичного дискурсу $€$ ритуальність i формальність, контекстуальність формулювань, інтертекстуальність, імпліцитна ідеологічність, чітке структурування концептуально-категоріального конструкту, толерантність і витримка часу в прийнятті рішень.

Серед його жанрового спектру виокремлюємо:

1) публічні виступи політиків та коментаторів, інтерв'ю політиків, засідання уряду, з'їзд партії (усна реалізація);

2) публікації у ЗМІ, історичні документальні хроніки, політико-нормативні документи (письмова реалізація).

Проаналізуємо лінгвістичні особливості оформлення китайськомовного військово-політичного дискурсу i наведемо деякі приклади інтерпретаціï ma відтворення специфікованих лінгвістичних та екстралінгвістичних семантичних маркерів українською мовою.

1. Термінологія $i$ фразеологізми військово-політичної спрямованості: 携带火箭的歼击机 (xiédài huǒjiàn de jiānjīīī) винищувач-ракетоносець (дослівний переклад - винищувач, що має ракети); 下蛋 (xià dàn) - скидати бомби, бомбити (денотативне 
значення - нести яйця); 间接侵略 (jiànjiē qīnlüè) - непряма агресія; 不法的占据 (bùfãde zhànjù) - незаконна окупація; 联合空军演习 (liánhé kōngjūn yănxí) - спільні навчання 3 повітряних сил; 防海 (fánghăi) - охороняти морське узбережжя; берегова оборона тощо.

Подекуди перекладачам необхідно звертатися до етимологічних джерел задля з'ясування повної картини ситуації та пошуку адекватних засобів відтворення китайськомовних фразеологічних зворотів українською мовою із збереженням автентичного концептуального «навантаження» оригінальних висловлювань:

《狐假虎威 (Hu jia hu wei)». Дослівно цей вираз можна перекласти так: «Лис хитрощами взяв силу тигра». 3 ним пов'язана байка, що зафіксована в книзі «Політика Воюючих царств»: «Якось тигр зібрався з '̈сти лиса, лис йому й каже: "Ти не можеш їсти мене, оскільки бог призначив мене царем звірів. Якщь ти з'їси мене, то порушиш наказ Бога. А якщзо не віриш мені, то йди слідом за мною й побачиш, щуо звірі як побачать мене, будуть утікати». Тигр пішов за лисом і побачив, щуо всі звірі як побачать їх, відразу втікають. Тигр подумав, щуо всі вони дійсно боялися лиса, він не знав, щзо насправді вони боялися його самого». Зараз цей вираз має таку інтерпретацію: «Творити зло, прикриваючись високими покровителями».

У більшості випадків серед розповсюджених прийомів виокремлюємо кальку, хоча без фонових знань, що є культурномаркованими, використаємо тактику лінгвістичної адаптації змісту автентичних висловлювань (речень).

2. Реaлiї: 台衷 (táigǔn), 首相 (shǒuxiàng) - прем’єpміністр, канцлер; 中国共产党第十八次代表大會 (Zhōngguó gòngchăndăng dì shíbā cì dàibiăo dàhuì) - XVIII з'їзд КПК; 中央军委装备发展部 (zhōngyāng jūnwěi zhuāngbèi fāzhăn bù) Центральна військова рада КНР; 中國民主同盟 (Zhōngguó mínzhǔ tóngméng) - Демократична ліга Китаю (ДЛК); 万里长城 (Wànlǐ Chángchéng) - Велика китайська стіна (обр. бути надійною опорою) тощо. Незалежно від історичного періоду інтерпретуємо реалії із застосуванням прийомів генералізації, описового перекладу та кальки.

Антропоніми, топоніми, хрононіми, ідеоніми, хрематоніми, ергоніми, гідроніми та етноніми в межах китайських реалій відтворюються засобами транслітерації, апроксимального 
транскодування, описового перекладу, кальки (за необхідністю додається коментар-інтерпретація): 習近平 (Xí Jìnpíng) - Ci Цзіньпін (транслітерація); 北京 (běijīng) - Пекін (апроксимальне транскодування); 东亚 (dōngyà) - Східна Азія (калька); 中国 中央电 视台 (Zhōng-guó Zhōng-yāng Diàn-shì-tái) - CCTV або Центральний Телеканал Китаю (калька + уточнення); 人民日报 (Rénmín Ribào) - Женьмінь жибао, *буквально «Народна щоденна газета» (транслітерація + коментар); 中国共产党 (Zhōngguó gòngchăndăng) Комуністична партія Китаю (калька); 黄河 (Huáng Hé) - Хуанхе, *Жовта ріка (транслітерація + коментар); 汉人 (hànrén) - ха́ньці, або кита́йці (морфемний переклад + уточнення) тощо.

3. Неологізми (нова політологічна термінологія).

Наведемо приклади неологізмів: 中纪委 (Zhōng jìwěi) - Центральна комісія 3 дисципліни (скорочено від «中央纪律检查委员会 / Центральна комісія 3 перевірки дисциплін»); 新丝绸之路 (Xīn sīchóu zhī lù) - Новий шовковий шлях (*Свразійський сухопутний міст); 一带一路 (Yīdài yīlù) «Один пояс - один шлях» (*концепція проекту «Новий шовковий шлях» щодо відродження стародавнього Великого Шовкового шляху, транспортного маршруту між Сходом і Заходом). Переклади політичних текстів, що містять неологізми, здійснюється на фундаменті змісту ключових концепцій цієї сфери, тобто йдеться про об'єктивну інтерпретацію контенту оригінального тексту. Доцільним вважається коментування змісту неологізму i / або уточнення його етимології.

4. Ідеологеми, політичні метафори.

Китайським ідеологемам притаманно образність, простота та запам'ятовуваність. На їх основі формується мобілізаційний потенціал влади для керівництва багаточисельним народом.

Наприклад：在自力更生基础上扩大开放，是我们必须长期坚持 的方针 (zài zì lì gēng shēng jīchǔ shàng kuòdà kāifàng shì wǒmen bìxū chángqī jiānchí de fāngzhēn) - розширення зовнішніх зв'язків на основі опори на власні сили є курсом, якого Китай повинен дотримуватися.

Ідеологема «自力更生 (zì lì gēng shēng) / на основі опори на власні сили» має конфуціанське розуміння «благородний муж», згідно якого «незалежність» асоціюють із «власними силами», що слід інтерпретувати як «покладатися на внутрішне виробництво 
валового продукту та імпортувати його в зарубіжні країни, що й визначає вектор довгострокового економічного розвитку Китаю».

В ідеологемі «十年内乱遗留下来的消极东西 (shínián nèiluàn yíliú xiàlai de xiāojí dōng xī) / спадщина десяти років внутрішнього хаосу», яку висловив Ден Сяопін на 2-му пленумі ЦК КПК 12-го скликання від 12 жовтня 1983 року, прихована інформація про особливості періоду «культурної революції», під час якої за різними джерелами загинуло кілька десятків мільйонів людей через певні діяння КПК.

Найчастіше при перекладі ідеологем використовується стратегія комунікативно-рівноцінного перекладу з метою збереження впливу, що зафіксований у тексті оригіналу, та, відповідно, реалізації комунікативної інтенції відправника вихідного повідомлення. Проте відзначимо, що припускається додавання коментаря українським реципієнтам задля розуміння імпліцитного культурно-маркованого автентичного підтексту.

Переклад-інтерпретація політичних метафор значною мірою пов'язаний із знаннями історії, філософії, літератури, культури, сучасного політико-економічного стану КНР: 日不落帝国 (dìguó yǒngyuăn bù luò de tàiyáng) - імперія, над якою ніколи не заходило сонце (про Велику Британію); 世界大同 - велике Сднання світу (соціальна утопія Сунь Ятсена); 我们祖国的心脏 - серце нашої батьківщини (про Пекін). Переклад $є$ комунікативно-рівноцінним із застосуванням стратегії переадресації, тобто створення додаткових текстових елементів для українського реципієнта, який відрізняється від носіїв китайської мови соціально-етнічними характеристиками.

5. Веньянізми.

y фpaзi «景大道既隐, 天下为公 (Jǐng dàdào jì yǐn, tiānxià wéi gōng) - дослівно: Коли діяло Велике Дао (або «коли йшли Великим шляхом»), Піднебесна належала всім, тобто була спільною» зустрічаємо веньянізми «大道» $\mathrm{i}$ 《天下», які потрібно відтворювати українською мовою з урахуванням сучасного контексту військовополітичного дискурсу. Пропонуємо таке тлумачення: «Нині, коли діє Новий Шовкових илях, Китай - це єдина родина» (функціональна заміна + заміна терміна).

Розглянемо ще один приклад із службовим слово «将 / jiāng», яке відноситься до веньюй та має декілька значень (одно 3 них детермінує майбутню дію чи намір): «中国将继续同广大发展中国家 
Psycholinguistic Aspects of Reproducing the Chinese Military...

站在一起 (zhōngguó jiāng jìxù tóng guăngdà fāzhănzhōng guójiā zhàn zàiȳ̄qū) - Китай буде i надалі стояти пліч-о-пліч 3 країнами, що розвиваються».

У силу відсутності в китайській мові граматичної категорії майбутнього часу, службове слово «将 / jiāng» в перекладі українською мовою було відтворено за допомогою форми майбутнього часу дієслова «бути» (функціональна заміна).

Веньянізми також застосовуються у поєднанні 3 ченьюями. Наприклад: 中华人民共和国走过了70年风风雨雨 (zhōnghuá rénmín gònghéguó zǒuguò le 70 nián fēngfēngyǔyǔ) - За минулі 70 років Китайська Народна Республіка пройшла складний шлях. Ченьюй «风风雨雨》 дослівно перекладається як «вітер, вітер, дощ, дощ», але в тексті перекладу він набуває значення «злигодні, труднощі, знегоди, перепони». При перекладі цього стійкого звороту було використано перекладацьку операцію експлікації для адекватного відтворення змісту висловлювання в мові перекладу.

6. Частки-інтенсифікатори.

Частки-інтенсифікатори функціонують як експресивнопідсилювальні елементи, покликані виділити структурні компоненти речення (слова, словосполучення). У тексті перекладу їх відтворюють відповідними частками чи іншими інтенсифікаторами. Наприклад: “ 局势吗, 并不那么严重 (júshì ma bìngbù nàme yánzhòng) - Ситуація не така вже серйозна» (частка, значення якої «справді, дійсно»).

Частка «着呢 (zhe ne)» має в українській мові такі відповідники, як-от: частка «вже», частка «як», прислівник «дуже, вельми»:

东亚峰会热闹着呢! (dōngyà fēnghuì rènao zhe ne!) - $\boldsymbol{Я}_{\boldsymbol{\kappa}}$ же жваво на Саміті країн Східної Азії!

四个月了, 这个问题还飞着呢！ (sì gè yuè le zhège wèntí hái fēizhe zhe ne) - Ця проблема вже чотири місяця залишається невирішеною.

Як свідчать наведені приклади, лексико-граматичні маркери китайськомовного військово-політичного дискурсу наділені узусною та культурною компонентами, вони $\epsilon$ концептуальнообгрунтованими та дискурсивно спрямованими, що необхідно відбивати в текстах перекладу.

Дослідження психолінгвістичних засобів відтворення детермінантів китайськомовного військово-політичного дискурсу 
українською мовою стало основою для проведення експерименту 3 оцінювання якості їх перекладу на базі Державного закладу «Південноукраїнський національний педагогічний університет імені К.Д. Ушинського». У першому семестрі першого року навчання (2018-2019 н.р.) здобувачі вищої освіти (20 осіб), які навчаються за другим (магістерським) рівнем (спеціальність «Переклад»), прослухали курс-модуль «Китайськомовний військовополітичний дискурс: психолінгвістичні детермінанти, засоби відтворення українською мовою» в межах навчальної дисципліни «Теорія і практика перекладу», після чого студентам було надано завдання перекласти 20 текстів обсягом до 2000 друкованих знаків, що репрезентують китайськомовний військово-політичний дискурсу (публічні виступи політиків та коментаторів, інтерв'ю політиків, протоколи засідань уряду, з'їздів партії, публікації у 3MI, історичні документальні хроніки, політико-нормативні документи), українською мовою. Як було зазначено вище, до експерименту було залучено 5 перекладачів, які оцінювали якість перекладу текстів за такими критеріями: • адекватний (добрий переклад); • задовільний переклад; • неадекватний (поганий переклад). Специфікуємо їх.

- Адекватний (добрий переклад): переклад, у якому відтворюється функціональна домінанта вихідного повідомлення відповідно до комунікативної інтенції відправника вихідного повідомлення; викликає адекватну реакцію одержувача цього повідомлення; наявність відповідного ступеня семантикоструктурної подібності перекладу вихідному тексту; лінгвістична коректність оформлення тексту перекладу.

- Задовільний переклад: переклад, у якому частково відтворюється функціональна домінанта вихідного повідомлення відповідно до комунікативної інтенції відправника вихідного повідомлення; у більшості випадків викликає адекватну реакцію одержувача цього повідомлення; наявність відповідного ступеня семантико-структурної подібності перекладу вихідному тексту; загальна лінгвістична коректність оформлення тексту перекладу (подекуди трапляються лексико-граматичні огріхи).

- Неадекватний (поганий переклад): перекладачем не декодовано зміст вихідного тексту, його призначення, комунікативну інтенцію автора; в силу мовної некомпетентності або незнання предмету мовлення перекладач припускає неточності, спотворення 
змісту, що призводить до передання інформації у викривленому виді; відсутність еквівалентності при зіставленні окремих сегментів (речень) текстів оригіналу i перекладу; наявність чисельних лінгвістичних огріхів і помилок в оформленні тексту перекладу.

За результатами експерименту було отримано такі дані: 76\% текстів перекладу було оцінено як адекватний переклад; 20\% - як задовільний; 4\% - як поганий переклад. Серед розповсюджених помилок було відмічено такі: 1) функціональна домінанта вихідного повідомлення була ідентифікована не в повному обсязі і, відповідно, відтворена частково; дещо порушено ступінь семантикоструктурної подібності перекладу вихідному тексту; спостерігалися лексико-граматичні огріхи (неузгодженість за відмінком в атрибутивних словосполученнях); неправильний вибір слова iз синонімічного ряду («дужа» замість «могутня» у словосполученні «могутня держсава»; «напад» замість «агресія» тощо) (задовільний переклад); 2) не декодовано і не відтворено зміст вихідного тексту, його призначення, комунікативну інтенцію автора; спотворено зміст оригінального тексту через незнання базових концептів студійованого дискурсу; відсутність еквівалентності при зіставленні окремих словосполучень i речень текстів оригіналу i перекладу; відсутність навичок правильно обирати відповідник під час опрацювання омонімів (维新 / wéixīn - реформа, оновлення у фразі 《戌戌维新 / Конституційна реформа та модернізація 1898 року» та 唯心 / wéixinn - ідеалізм у словосполучення «绝对唯心主义 / абсолютний ідеалізм»; 司法 / sīfă - юстиція у словосполученні 《司法机关 / Міністерство юстиціï» i 私法 / sī fă - приватне право у фразі «国际私法 / Міжнародне приватне право» тощо); наявність чисельних лінгвістичних огріхів i помилок в оформленні тексту перекладу (неадекватний / поганий переклад).

Отже, докладне вивчення сутності китайськомовного військово-політичного дискурсу дозволило виокремити його психолінгвістичні детермінанти та дібрати адекватні засоби їх відтворення українською мовою, 3 одного боку; 3 іншого, - було експериментально доведено доречність практичного використання отриманих знань з порушеної теми.

Отримані результати підтверджують той факт, що різні мови по-різному впливають на процес сприйняття інформації, 
інтерпретації мовного сигналу; кожний соціум спирається на історично складені мовні нормативи та когнітивні основи психолінгвістичної комунікативної діяльності.

\section{Висновки}

У межах започаткованого дослідження можна дійти таких висновків:

1. Концептуальну базу детермінантів китайськомовного військово-політичного дискурсу складають психолінгвістичні феномени: дискурс, концепт, концептосфера, лінгвістична компонента, екстралінгвістична компонента.

2. Ключові поняття визначено та специфіковано через національно- i культурно-марковані елементи, концептуальний фундамент та лінгвістичну маніфестацію досліджуваного дискурсу.

3. Серед психолінгвістичного конструкту актуалізації китайськомовного військово-політичного дискурсу виокремлено такі мовні явища, як-от: термінологія і фразеологізми військовополітичної спрямованості; реалії; ідеологеми, політичні метафори; веньянізми; частки-інтенсифікатори. Під час перекладу термінології i фразеологізмів військово-політичної спрямованості превалює перекладацький прийом калькування (пошук еквівалента). Під час відтворення китайськомовних реалій, ідеологем, політичної метафори, веньянізмів доводиться вдаватися до описового перекладу, коментарю. Власні назви 3 категорії «реалії» (оніми) репродукуємо засобами транслітерації, транскодування, кальки. Частки-інтенсифікатори відтворюємо відповідними частками чи іншими інтенсифікаторами. Відзначимо, що адекватність тексту перекладу забезпечили стратегія комунікативно-рівноцінного перекладу і стратегія переадресації 3 поширеним використанням тактики лінгвокультурної адаптації.

Результати проведеного дослідження слід розглядати як стартовий етап у студіюванні китайськомовного військовополітичного дискурсу. Перспективним вважаємо подальше вивчення тактико-стратегічних векторів відтворення синтаксичної складової досліджуваного дискурсу українською мовою. 


\section{Література}

Арутюнова Н.Д. Дискурс. Лингвистический энциклопедический словарь. Москва: Советская энциклопедия, 1990. 684 с.

Бацевич Ф.С. Нариси $з$ лінгвістичної прагматики. Львів: ПАІС, 2010. 336 с.

Бацевич Ф.С. Основи комунікативної лінгвістики. Київ: Академія, 2004. 344 с.

Бехта I.A. Дискурс наратора в англомовній художній прозі. Київ: Грамота, 2004. 304 c.

Болдырев Н.Н. Когнитивная семантика. Тамбов: Изд-во Тамб. гос. ун-та, 2001. 123 c.

Ван Сюй. Особенности политической культури Китая. Общество. Среда. Развитие. 2016. Вып. 3. С. 57-62.

Греймас А.-Ж., Курте Ж. Семиотика. Объяснительный словарь теории языка. Москва, 1983. С. 481-550.

Жаботинская С.А. Принципы создания ономасиологических моделей и событийных схем в языке. Горизонты современной лингвистики: Традиции и новаторство: Сборник в честь Е.С. Кубряковой. Москва: Языки славянских культур, 2009. С. 381-401.

Залевская А.А. Психолингвистический подход к проблеме концепта. Методологические проблемь когнитивной лингвистики / Отв. ред. И.А. Стернин. Воронеж: ВГУ, 2001. С. 36-44.

Ищенко Н.А. Военный дискурс и дискурсивное измерение войны. Культура народов Причерноморья. 2007. Вып. 116. С. 22-24.

Карасик В.И. О типах дискурса. Языковая личность: институцииональный и персональный дискурс. Волгоград: Перемена, 2000. С. 5-20.

Конт-Спонвиль А. Философский словарь / Пер. с фр. Е.В. Головиной. Москва: Этерна, 2012. 752 с.

Красных В.В. Основы психолингвистики и теории коммуникации. Москва: ИТДГК «Гнозис», 2001. 270 с.

Кубрякова Е.С. Об одном фрагменте концептуального анализа слова «память». Логический анализ языка. Культурные конщептыл. Москва: Наука, 1991. C. 85-91.

Кубрякова Е.С. Предисловие. Концептуальный анализ языка: Современные направления исследования. Москва: РАН. Ин-т языкознания; ТГУ им. Г.Р. Державина, 2007. С. 7-19.

Леонтьев А.А. Язык, речь, речевая деятельность. Москва: «Просвещение», 1969. $214 \mathrm{c}$.

Леонтьев А.А. Психологическая структура значения. Семантическая структура слова: психолингвистические исследования / Отв. ред. А.А. Леонтьев. Москва, 1971. С. 7-18.

Мартинюк А.П. Словник основних термінів когнітивно-дискурсивної лінгвістики. Харків: ХНУ імені В.Н. Каразіна, 2011. 196 с.

Маслова В.А. Лингвокультурология. Москва: Академия, 2001. 208 с.

Павиленис Р.И. Проблема смысла. Современный логико-философский анализ языка. Москва: Наука, 1983. 286 с.

Попова З.Д., Стернин И.А. Понятие концепт в лингвистических исследованиях. Воронеж, 1999. 30 с. 
Райзберг Б.А. Современный социоэкономический словарь. Москва: ИНФРА-М, 2009. 629 с.

Ребрій О., Ребрій I. Системність і творчість у перекладі: психолінгвістичний підхід. Psycholinguistics. Психолінгвістика. Психолингвистика. 2018. Вип. 23(2). С. 180-191. https://doi.org/10.5281/zenodo.1199186

Салмери С. Коммуникация и герменевтика в рамках инклюзии [Электронный pecypc]. Язык и текст. 2016. Том 3. № 1. С. 63-70. https://doi.org/10.17759/ langt.2016030107

Серио П. Как читают тексты во Франции. Квадратура смысла. Франиузская школа анализа дискурса. Москва: Прогресс, 1999. С. 14-53.

Толстой Н.И. Некоторые соображения о реконструкции славянской духовной культуры. Славянский и балканский фольклор. Реконструкция древней славянской духовной культуры: источники и методы / Отв. ред. Н.И. Толстой. Москва: Наука, 1989. С. 7-22.

Уорф .Л. Отношение норм поведения и мышления к языку. Новое в лингвистике. Москва, 1960. Вып. 1. С. 135-168.

Фуко М. Археология знания. Киев: Ника-Центр, 1996. 208 с.

Шейгал Е.И. Семиотика политического дискурса. Москва: Гнозис, 2004. 326 с.

Budniak, D (2003). Triada: etnos, język, kultura Słowian. Kyïv: Vydavnyčyj Dim Dmytra Burago.

De Deyne S., \& Storms, G. (2008). Word associations: Network and semantic properties. Behavior Research Methods, 40(1), 213-231. https://doi.org/10.3758/ BRM.40.1.213

Habermas, J. (1981). Theorie des kommunikativen Handelns. Handlungsrationalität und gesellschaftliche Rationalisierung. Frankfurt am Main.

Hatzidaki, A. (2007). The Process of Comprehension from a Psycholinguistic Approach - Implications for Translation. Meta, 52(1), 13-21. https://doi. org/10.7202/014715ar

Reitter, D. (2016). Alignment in web-based dialogue: Who aligns, and how automatic is it? Studies in big-data computational psycholinguistics. In Big Data in Cognitive Science (pp. 246-269). Taylor and Francis. https://doi. org/10.4324/9781315413570

\section{References}

Arutyunova, N.D. (1990). Diskurs. Lingvisticheskiy entsiklopedicheskiy slovar [Discourse. Linguistic Encyclopedic Dictionary]. Moscow: Sovetskaya entsiklopediya [in Russian].

Batsevych, F.S. (2010). Narysy z linhvistychnoi prahmatyky [Essays on linguistic pragmatics]. Lviv: PAIS [in Ukrainian].

Batsevych, F.S. (2004). Osnovy komunikatyvnoi linhvistyky [Basics of communicative linguistics]. Kyiv: Akademiia [in Ukrainian].

Bekhta, I.A. (2004). Dyskurs naratora $v$ anhlomovnii khudozhnii prozi [Discourse of the narrator in English-language artistic prose]. Kyiv: Hramota [in Ukrainian].

Boldyrev, N.N. (2001). Kognitivnaya semantika [Cognitive semantics]. Tambov: Izd-vo Tamb. gos. un-ta [in Russian]. 
Wan, Xiu. (2016). Osobennosti politicheskoy kulturi Kitaya [Peculiarities of the political culture of China]. Obshchestvo. Sreda. Razvitiye - Society. Environment. Development, 3, 57-62 [in Russian].

Greimas, A.J., \& Courtes, J. (1983). Semiotika. Obyasnitelnyy slovar teorii yazyka [Semiotics. Explanatory dictionary of theory of language]. Moscow [in Russian].

Zhabotinskaya, S.A. (2009). Printsipy sozdaniya onomasiologicheskikh modeley i sobytiynykh skhem $\mathrm{v}$ yazyke [Principles of creating onomasiological models and event schemes in the language]. Gorizonty sovremennoy lingvistiki: Traditsii $i$ novatorstvo - The horizons of modern linguistics: Tradition and innovation, (pp. 381-401). Moscow: Yazyki slavyanskikh kultur [in Russian].

Zalevskaya, A.A. (2001). Psikholingvisticheskiy podkhod $\mathrm{k}$ probleme kontsepta [Psycholinguistic approach to the concept problem]. Metodologicheskiye problemy kognitivnoy lingvistiki - Methodological problems of cognitive linguistics. I.A. Sternin (Ed.), (pp. 36-44). Voronezh: VGU [in Russian].

Ishchenko, N.A. (2007). Voyennyy diskurs i diskursivnoye izmereniye voyny [Military Discourse and Discursive Dimension of War]. Kultura narodov Prichernomoria Culture of the peoples of the Black Sea region, 116, 22-24 [in Russian].

Karasik, V.I. (2000). O tipakh diskursa [About types of discourse]. Yazykovaya lichnost: institutsionalnyy i personalnyy diskurs - Linguistic identity: institutional and personal discourse, (pp. 5-20). Volgograd: Peremena [in Russian].

Kont-Sponvil, A. (2012). Filosofskiy slovar [Philosophical Dictionary]. (E. Golovina, Trans). Moscow: Eterna [in Russian].

Krasnyih, V.V. (2001). Osnovyi psiholingvistiki i teorii kommunikatsii [Fundamentals of psycholinguistics and communication theory]. Moscow: ITDGK «Gnozis» [in Russian].

Kubryakova, E.S. (1991). Ob odnom fragmente kontseptualnogo analiza slova «pamyat» [Regarding a fragment of the conceptual analysis of the word «memory»]. Logicheskiy analiz yazyka. Kulturnyye kontsepty - Logical analysis of the language. Cultural concepts, (pp. 85-91). Moscow: Nauka [in Russian].

Kubryakova, E.S. (2007). Predisloviye [Foreword]. Kontseptualnyy analiz yazyka: Sovremennyye napravleniya issledovaniya - Conceptual analysis of the language: Modern areas of research, (pp. 7-19). Moscow: RAN. In-t yazykoznaniya; TGU im. G.R. Derzhavina [in Russian].

Leontev, A.A. (1969). Yazyik, rech, rechevaya deyatelnost [Language, speech, speech activity]. Moscow: «Prosveschenie» [in Russian].

Leontev, A.A. (1971). Psihologicheskaya struktura znacheniya [Psychological structure of meaning]. Semanticheskaya struktura slova: psiholingv. issled - The semantic structure of the word: psycholinguistic studies. A.A. Leontev (Ed.). Moscow: Akad. nauk SSSR, In-t yazyikoznaniya [in Russian].

Martyniuk, A.P. (2011). Slovnyk osnovnykh terminiv kohnityvno-dyskursyvnoi linhvistyky [The dictionary of the main terms of cognitive-discursive linguistic studies]. Kharkiv: KhNU imeni V.N. Karazina [in Ukrainian].

Maslova, V.A. (2001) Lingvokulturologiya [Linguoculturology]. Moscow: Akademiya [in Russian].

Pavilenis, R.I. (1983). Problema smysla. Sovremennyy logiko-filosofskiy analiz yazyka [The problem of meaning. Modern logical-philosophical analysis of language]. Moscow: Nauka [in Russian].

Popova, Z.D., \& Sternin, I.A. (1999). Ponyatiye kontsept $v$ lingvisticheskikh issledovaniyakh [The notion concept in linguistic studies]. Voronezh [in Russian]. 
Reisberg, B.A. (2009). Sovremennyy sotsioekonomicheskiy slovar [Modern Socioeconomic Dictionary]. Moscow: INFRA-M [in Russian].

Rebrii, O., \& Rebrii, I. (2018). Cistemnist i tvorchist u perekladi: psikholingvistichniy pidkhid [Systemic and Creative Aspects of Translation: Psycholinguistic Approach]. Psyholingvistyka - Psycholinguistics, 23(2), 180-191. https://doi. org/10.5281/zenodo.1199186 [in Ukrainian].

Salmeri, S. (2016). Kommunikatsiya i germenevtika v ramkakh inklyuzii [Communication and hermeneutics for inclusion]. Azyk $i$ tekst - Language and Text, 3(1), 63-70. https://doi.org/10.17759/langt.2016030107 [in Russian].

Serio, P. (1999). Kak chitayut teksty vo Frantsii [How one reads texts in France]. Kvadratura smysla. Frantsuzskaya shkola analiza diskursa - Meaning quadrature. French school of discourse analysis, (pp. 14-53). Moscow: Progress [in Russian].

Tolstoy, N.I. (1989). Nekotoryye soobrazheniya o rekonstruktsii slavyanskoy dukhovnoy kultury [Some thoughts regarding the reconstruction of Slavic spiritual culture]. Slavyanskiy i balkanskiy folklor. Rekonstruktsiya drevney slavyanskoy dukhovnoy kultury: istochniki i metody - Slavic and Balkan folklore. Reconstruction of the ancient Slavic spiritual culture: sources and methods, (pp. 7-22). Moscow: Nauka [in Russian].

Whorf, B.L. (1960). Otnosheniye norm povedeniya i myshleniya $\mathrm{k}$ yazyku [Relationship of the norms of behaviour and mind-set to language]. Novoye $v$ lingvistike - New in Linguistics, 1, 135-168 [in Russian].

Fuko, M. (1996). Arkheologiya znaniya [Archeology of knowledge]. Kyiv: Nika-Tsentr [in Russian].

Sheygal, E.I. (2004). Semiotika politicheskogo diskursa [Semiotics of political discourse]. Moscow: Gnozis [in Russian].

Budniak, D (2003). Triada: etnos, język, kultura Słowian. Kyïv: Vydavnyčyj Dim Dmytra Burago.

De Deyne S., \& Storms, G. (2008). Word associations: Network and semantic properties. Behavior Research Methods, 40(1), 213-231. https://doi.org/10.3758/ BRM.40.1.213

Habermas, J. (1981). Theorie des kommunikativen Handelns. Handlungsrationalität und gesellschaftliche Rationalisierung. Frankfurt am Main.

Hatzidaki, A. (2007). The Process of Comprehension from a Psycholinguistic Approach - Implications for Translation. Meta, 52(1), 13-21. https://doi. org/10.7202/014715ar

Reitter, D. (2016). Alignment in web-based dialogue: Who aligns, and how automatic is it? Studies in big-data computational psycholinguistics. In Big Data in Cognitive Science (pp. 246-269). Taylor and Francis. https://doi. org/10.4324/9781315413570

\section{АНОТАЦІЯ}

Стаття присвячена висвітленню психолінгвістичних проблем варіативності інтерпретації та лінгвокультурної адаптації концептуальної бази детермінантів китайськомовного військово-політичного дискурсу. Актуальність зумовлена неабияким інтересом науковців у галузі психолінгвістики, лінгвокультурології, перекладознавства до змістового контенту картини світу 
етносу країн Сходу. У роботі специфіковано детермінанти китайськомовного військово-політичного дискурсу (дискурс, концепт, концептосфера, лінгвістична компонента, екстралінгвістична компонента). Китайськомовний військовополітичний дискурс тлумачимо як сукупність вербалізованих усних і письмових текстів, створених у контексті політико-зорієнтованого спілкування; ідеографічно-символічне втілення начіонально-маркованої концептосфери, що регламентується народо- й культуроцентричними тактико-стратегічними векторами безконфліктної взаємодії інтерлокуторів у сфері політикоекономічних, військово-промислових, міннародних відносин. Виокремлено лінгвістичні явища, що сприяють актуалізації китайськомовного військовополітичного дискурсу, та засоби їх відтворення українською мовою (калька (пошук еквіваленту), транслітерація, транскодування, описовий переклад, коментар; стратегія комунікативно-рівноцінного перекладу і стратегія переадресації з поширеним використанням тактики лінгвокультурної адаптації). Перспективним вважаємо подальще вивчення психолінгвістичних аспектів тактико-стратегічних векторів відтворення синтаксичної складової досліджуваного дискурсу українською мовою.

Ключові слова: китайськомовний військово-політичний дискурсу, концепт, концептосфера, картина світу, мова, культура, засоби відтворення.

\title{
Королёва Татьяна, Попова Александра. Психолингвистические аспекты воспроизведения китаеязычного военно-политического дискурса на украинский язык
}

\begin{abstract}
АННОТАЦИЯ
Статья посвящена освещению психолингвистических проблем вариативности интерпретации и лингвокультурной адаптации концептуальной базы детерминантов китаеязычного военно-политического дискурса. Актуальность обусловлена большим интересом ученых в области психолингвистики, лингвокультурологии, переводоведения к смысловому контенту картины мира этноса стран Востока. В работе специфицированы детерминанты китаеязычного военно-политического дискурса (дискурс, концепт, концептосрера, лингвистическая компонента, экстралингвистическая компонента). Под китаеязычным военно-политическим дискурсом понимаем совокупность вербализованных устных и письменных текстов, созданных в контексте политико-ориентированного общения; идеографическисимволическое воплощение национально-маркированной концептосферы, которая регламентируется народо- и культуроцентричнимыми тактикостратегическими векторами бесконфликтного взаимодействия интерлокуторов в срере политико-экономических, военно-промышленных, международных отношений. Выделены лингвистические явления, способствующие актуализации китаеязычного военно-политического дискурса, и средства их воспроизведения на украинском языке (калька
\end{abstract}


Психолінгвістичні аспекти відтворення китайськомовного...

(поиск эквивалента), транслитерация, транскодирования, описательный перевод, комментарий; стратегия коммуникативно-равноценного перевода и стратегия переадресации с распространенным использованием тактики лингвокультурной адаптации). Перспективным считаем дальнейшее изучение тактико-стратегчческих векторов воспроизведения синтаксической составляющей исследуемого дискурса на украинском языке.

Ключевые слова: китаеязычный военно-политический дискурса, концепт, концептосфера, картина мира, язык, культура, средства воспроизведения. 